\title{
Isolation of Cellulose-Degrading Endophyte from Capsicum chinense and Determination of its Cellulolytic Potential
}

\author{
Angkita Sharma ${ }^{\text {(D) }}$, Pooja Singh ${ }^{1(D)}$, Bidyut Kumar Sarmah ${ }^{2}$, Shoma Paul Nandi 1,* (D) \\ Amity Institute of Biotechnology, Amity University, Noida-201313, Uttar Pradesh \\ Assam Agricultural University (AAU) Jorhat-785013, Assam \\ * Correspondence: spaul@amity.edu;
}

Scopus Author ID 36731454500

Received: 15.04.2020; Revised: 22.05.2020; Accepted: 24.05.2020; Published: 1.06.2020

\begin{abstract}
Knowledge in the field of bacterial endophytes associated with the plant Capsicum chinense is negligible. So in order to characterize the endophytic population in the targeted plant, different accessions of $C$. chinense plant were procured from different agro-climatic zones of India. Bacterial endophytes were isolated by using standard protocols. After isolation of the endophytes, a biochemical identification study was performed using the standard key. Secondary metabolites of these bacterial species were studied for their economic importance. One isolate of cellulose-degrading bacteria (CDB) was isolated from the roots of $C$. chinense. The cellulase activity of the endophyte, containing cellulose Congo Red agar. Finally, enzyme assays for the cellulase (endoglucanase) and filter paper cellulase or FPC assay was studied. The maximum clearing zone for the isolate was $50 \mathrm{~mm}$, and the hydrolytic capacity (HC) was found to be 5.96. The endoglucanase activity of $0.95 \mathrm{IU} / \mathrm{mL}$ and the filter paper Filter Paper Cellulase (FPCase) activity was found to be $0.25 \mathrm{IU} / \mathrm{mL}$. The importance of the study is attributed to the fact that this is the first-ever study of the enzymatic activity of endophytic bacteria isolated from $C$. chinense collected from North-East India.
\end{abstract}

Keywords: Capsicum chinense; bacterial endophytes; secondary metabolites; cellulolytic activity; cellulase enzyme.

(C) 2020 by the authors. This article is an open-access article distributed under the terms and conditions of the Creative Commons Attribution (CC BY) license (https://creativecommons.org/licenses/by/4.0/).

\section{Introduction}

Plants live closely associated with the microorganisms that are present in their vicinity, and more specifically, so with the ones that live internally. Endophytes are microbes, both fungi, and bacteria, which reside in an asymptomatic manner in the roots and aerial tissues of plants [1]. Various fungal and bacterial endophytes network with higher plant phylum. Interactions with mutualistic interests that led to malleable profits for the two species sometimes evolved to a higher level of intricate forms that involved more than one partner [2, 3]. The north-eastern region of India, which is a major biodiversity hot spot areas of the world, shelters a gamut of plants and their associated endophytes [4]. Endophytic bacteria increase the host plant's resistance to biotic and abiotic stresses by producing diverse bioactive compounds, such as diterpenes, flavonoids, alkaloids, and isoflavonoids. Some endophytic bacteria endorse the increase of secondary metabolite production of the host plants, which include important medicinal components or environmentally friendly compounds. 
Plant biomass is considered the most profusely available organic carbon source present in the biosphere. A greater part of this carbon remains confined in cell wall polymers. The very complex structure of the polymer is attributed to the presence of cellulose, hemicelluloses, and lignin, along with pectins and structural proteins. Thus, the industrial breakdown of this material to simple forms require extreme physicochemical environments and/or a lot of diverse enzymes [5].

The enzyme system of cellulose manages cellulolysis, which is a naturally occurring biological process. There are three different classes of soluble extracellular enzymes in the cellulase enzyme system, namely: $1,4-\beta$-exoglucanase, $1,4-\beta$-endoglucanase, and $\beta$ glucosidase (Cellobiase). The enzyme endoglucanase is accountable for the arbitrary snipping of the glycosidic bonds $(\beta-1,4)$. The enzyme exoglucanase, on the other hand, is needed for breach of the non-reducing side of the cellulose chain. Eventually, it snips off the central fibrils off the crystalline form of cellulose, when $\beta$-1, 4-glucosidase breaks cellobiose along with cellodextrin forming glucose $[6,7]$. Interaction of these enzymes only makes it possible to completely hydrolyze cellulose to glucose $[8,9]$ or a complete degradation to $\mathrm{H}_{2} \mathrm{O}$ and $\mathrm{CO}_{2}$. Cellulase enzyme, because of its huge potential, has been employed in many industrial processes, such as plant waste management and biofuels [10, 11]; triphasic biomethanation [12] bioethanol [13, 14], etc.

Bhut jolokia, scientific name Capsicum Chinense Jaqc, from the family Solanaceae is placed among the hottest chilies along with 'Trinidad Moruga Scorpion' and is reported to be an indigenous cultivar, which mostly grows in Nagaland, Manipur and the Brahmaputra flood plain of Assam. C. chinense is a well-known medicinal plant, which is used in traditional medication as an excellent source for Vitamin C (Ascorbic acid), carotenoid, Vitamin E (tocopherols), capsaicinoids, and flavonoids. Capsaicin (8-methyl-N-vanillyl-6-nonenamide) along with dihydrocapsaicin are considered the key capsaicinoids found in hot peppers. Homodihydrocapsaicin, nordihydrocapsaicin, and homocapsaicin are the ones present in lower amounts [15]. A measurement to calculate the pungency was established by Wilbur Scoville; total capsaicinoids are able to be altered to Scoville heat units [16]. C. chinense is attributed to having a lot of medicinal properties with immense pharmacological actions. These include antitumor, antibacterial, anti-arthritic, anti-inflammatory, and antioxidant properties. However, the environmental aspects of this plant and its associated endophytes have not been studied so far.

The current work focusses on isolation and identification of cellulose-degrading bacterial endophytes from the roots of Capsicum chinense plant collected from North-east India.

\section{Materials and Methods}

\subsection{Collection site.}

C. chinense plant was collected from the remote areas of Arunachal Pradesh, in the summer season, in the month of April. Samples were aseptically transferred into different zipped sterile polythene bags and then transported to the laboratory at room temperature [17].

\subsection{Isolation of endophyte.}

Endophyte was isolated using a standard protocol. Surface sterilization was done using $70 \%$ ethanol and $4 \%$ sodium hypochlorite solution. To remove any kind of adherents on the 
plant surface, it was washed properly under running tap water. After drying, the plant roots were cut into small segments approximately $1-2 \mathrm{~cm}$ in length. This whole procedure was carried out in laminar airflow. Plant segments were rinsed with $75 \%$ ethanol for 1 min and then with $4 \%$ sodium hypochlorite solution for $10 \mathrm{~min}$. This was followed by immersing the segments in $75 \%$ ethanol for $1 \mathrm{~min}$. Finally, all the plant segments were rinsed thrice with sterilized distilled water and were allowed to air dry. The sample was then ground using mortar and pestle, and the extract was plated in Nutrient Agar (NA) plates. The plates were incubated at $37^{\circ} \mathrm{C}$ for bacteria overnight [18].

\subsection{Morphological and Biochemical identification of the isolated bacteria.}

In order to confirm the cell morphology and the classification of the bacterial endophyte, general morphology was studied, and Gram staining was done with 100X optical microscopic visualization. Conventional biochemical tests, including the Indole test, Methyl red, Voges- Proskauer, Citrate test, Triple-Sugar Iron test, were done for the identification of the isolate [19].

\subsection{Total protein estimation.}

The total protein estimation of the isolate was done by Lowry method of protein estimation. Reagents required are BSA stock solution $(1 \mathrm{mg} / \mathrm{ml})$, the analytical reagents include (a) $50 \mathrm{ml}$ of $2 \%$ sodium carbonate with $50 \mathrm{ml}$ of $0.1 \mathrm{~N} \mathrm{NaOH}$, (b) $10 \mathrm{ml}$ of Copper sulphate $(1.56 \%)$ solution with $10 \mathrm{ml}$ of sodium-potassium tartrate $(2.37 \%)$ solution. This analytical reagent was prepared by mixing $2 \mathrm{ml}$ of the solution (b) with $100 \mathrm{ml}$ of solution (a). The FolinCiocalteau reagent $(1 \mathrm{~N})$ was obtained by diluting commercial reagent $(2 \mathrm{~N})$ with an equal volume of water freshly prepared every time [20,21]. The total protein concentration in the sample was recorded by reading the absorbance at $750 \mathrm{~nm}$ of the end product of the Folin reaction against a standard curve of Bovine Serum Albumin (BSA). $0.05 \mathrm{~g}$ of BSA was weighed and added to a $500 \mathrm{~mL}$ volumetric flask with ddl water. The volume was adjusted to $500 \mathrm{~mL}$ with ddl water. The final concentration of the BSA stock was made to $100 \mathrm{mg} / \mathrm{L}$.

\subsection{Screening of Cellulose-degrading capacity of the isolated bacteria.}

Bacterial endophyte isolates feeding on cellulose as a carbon source was isolated on agar media enriched with cellulose with a composition of $\mathrm{KH}_{2} \mathrm{PO}_{4} 0.50 \mathrm{~g}$ along with $\mathrm{MgSO}_{4}$ $0.27 \mathrm{~g}$. Other components include gelatin $2.0 \mathrm{~g}$; cellulose $2.0 \mathrm{~g}$; and agar $15 \mathrm{~g}$. 1Ldistilled water was added, and the $\mathrm{pH}$ was maintained at 6.8-7.2. For the determination of the isolate's capacity to degrade cellulose, cellulose CongoRed agar media was used, which was enriched with $\mathrm{KH}_{2} \mathrm{PO}_{4}$ 0.5.0 g and $\mathrm{MgSO}_{4} 0.25 \mathrm{~g} .15 \mathrm{~g}$ of agar was then added to $0.2 \mathrm{~g}$ Congo-Red, along with $2 \mathrm{~g}$ gelatin and $2 \mathrm{~g}$ cellulose. $1 \mathrm{~L}$ distilled water was added with a $\mathrm{pH}$ maintained at 6.8 7.2. Congo-Red, which indicates the cellulose-degrading ability of the isolate in an agar media, is a subtle and quick screening test for the cellulose-degrading capability of the endophyte. The quantitative estimation of the degradation ability of the isolate was done by computing the hydrolysis capacity [22, 23].

\subsection{Enzyme Production and estimation.}

The isolated cellulose-degrading bacteria $(\mathrm{CDB})$ was cultured at $37^{\circ} \mathrm{C}$ at $150 \mathrm{rpm}$ for enzyme production with a media composition of $\mathrm{KH}_{2} \mathrm{PO}_{4} 0.5 .0 \mathrm{~g}$ and $\mathrm{MgSO}_{4} 0.25 \mathrm{~g}$, along 
with gelatin $2.0 \mathrm{~g}$; 1 liter distilled water was added containing Whatman filter paper 1 with a measurement of $1 \times 6 \mathrm{~cm}$ strip or $0.050 \mathrm{~g}$ in $20 \mathrm{~mL}$ (pH of $6.8-7.2$ ). The optical density (OD $600 \mathrm{~nm})$ was measured every 3 hours for 72 hours. The cellulase was harvested at the optimum incubation time with the value of the highest cellulase activity. The broth culture incubated for three days period was then centrifuged at around $5000 \mathrm{rpm}$ for 10 minutes at $4^{\circ} \mathrm{C}$. The crude enzyme was the supernatant that was collected, which was then kept at $4^{\circ} \mathrm{C}$ for further assay studies $[24,25,26]$.

\subsection{Enzyme Assay.}

The cellulose-degrading activity of the isolate was checked by computing, reducing sugar concentration formed after the degradation of the filter paper. The enzyme assay was carried out according to the approvals of the International Union of Pure and Applied Chemistry (IUPAC) commission [31] on biotechnology. The endoglucanase activity was calculated by incubation of $0.5 \mathrm{~mL}$ of the supernatant obtained with $0.5 \mathrm{~mL}$ amorphous cellulose $(2 \%)$ in a buffer system (sodium citrate buffer with a $\mathrm{pH}$ of 4.8 ) at a temperature of 50 degrees for $30 \mathrm{~min}$. Similarly, the FPC enzymatic activity was calculated by the incubation of the supernatant $(0.5 \mathrm{~mL})$ with $1.0 \mathrm{~mL}$ of the buffer (sodium citrate buffer) having $0.05 \mathrm{M}$ at $\mathrm{pH} 4.8$. This was enhanced with the Whatman no.1 filter paper cut in the measurements $1.0 \times$ $6.0 \mathrm{~cm}$. After the incubation process for $1 \mathrm{~h}$ at a temperature of $50^{\circ} \mathrm{C}, 3,5$-dinitrosalicylic acid (DNS) reagent $(3 \mathrm{~mL})$ was added to the reaction to end it along with the reaction mixture (1 $\mathrm{mL}$ ). The reducing sugars were assessed with the help of a spectrophotometer along with DNS reagent [27] with glucose used as standards. The enzymatic activity was defined in international units (IU). The amount of enzyme releasing $1 \mu \mathrm{mol}$ reducing sugars (measured as glucose) per $\mathrm{mL}$ per minute measures one unit of enzymatic activity [23, 28, 29, 30, 31].

\subsection{Statistical analysis.}

A one-way ANOVA was carried out to check the significance of the results at $\mathrm{P}$ $(<0.005)$ between the two groups, and the tests were run in triplicates.

\section{Results and Discussion}

\subsection{Isolation, screening, and identification of the cellulase producing endophyte.}

Out of the total population of endophytes isolated from the roots of $C$. chinense, five showed cellulolytic potential, of which one showed the most potential. The study was carried forward with this particular isolate, termed Cb1 (Fig 1).

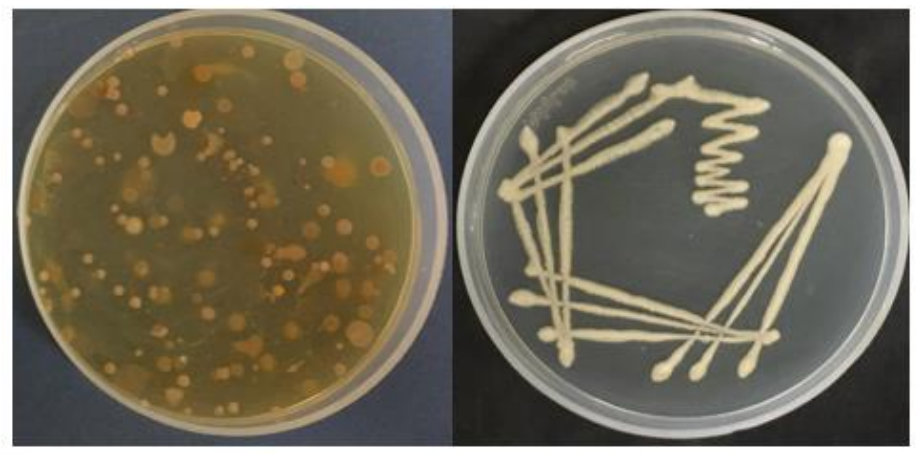

A

$\mathrm{B}$

Figure 1. A. Different bacterial endophytes from $C$ chinense; B. Isolate $\mathrm{Cb} 1$. 
The morphological attributes of the isolated strain $\mathrm{Cb} 1$ are given in Table 1 .

Table 1. Morphological characterization of the bacterial isolate $\mathrm{Cb} 1$.

\begin{tabular}{l|l}
\hline Isolate code & Cb1 \\
\hline Color & Orange Yellow \\
\hline Opacity & opaque \\
\hline Surface & smooth \\
\hline Form & circular \\
\hline Elevation & raised \\
\hline Margin & entire \\
\hline
\end{tabular}

The biochemical characteristics of the isolate are given in Table 2.

Table 2. Biochemical characterization of the bacterial isolate.

\begin{tabular}{|c|c|c|}
\hline Isolate code & Cb1 & Images \\
\hline Gram stain & Negative & - \\
\hline Shape & rod long & - \\
\hline Sulphide & Negative & \\
\hline Motility & Negative & - \\
\hline Indole & Negative & \\
\hline Methyl red & Positive & \\
\hline Voges Prauskeur & Positive & \\
\hline Citrate utilization & Positive & \\
\hline
\end{tabular}




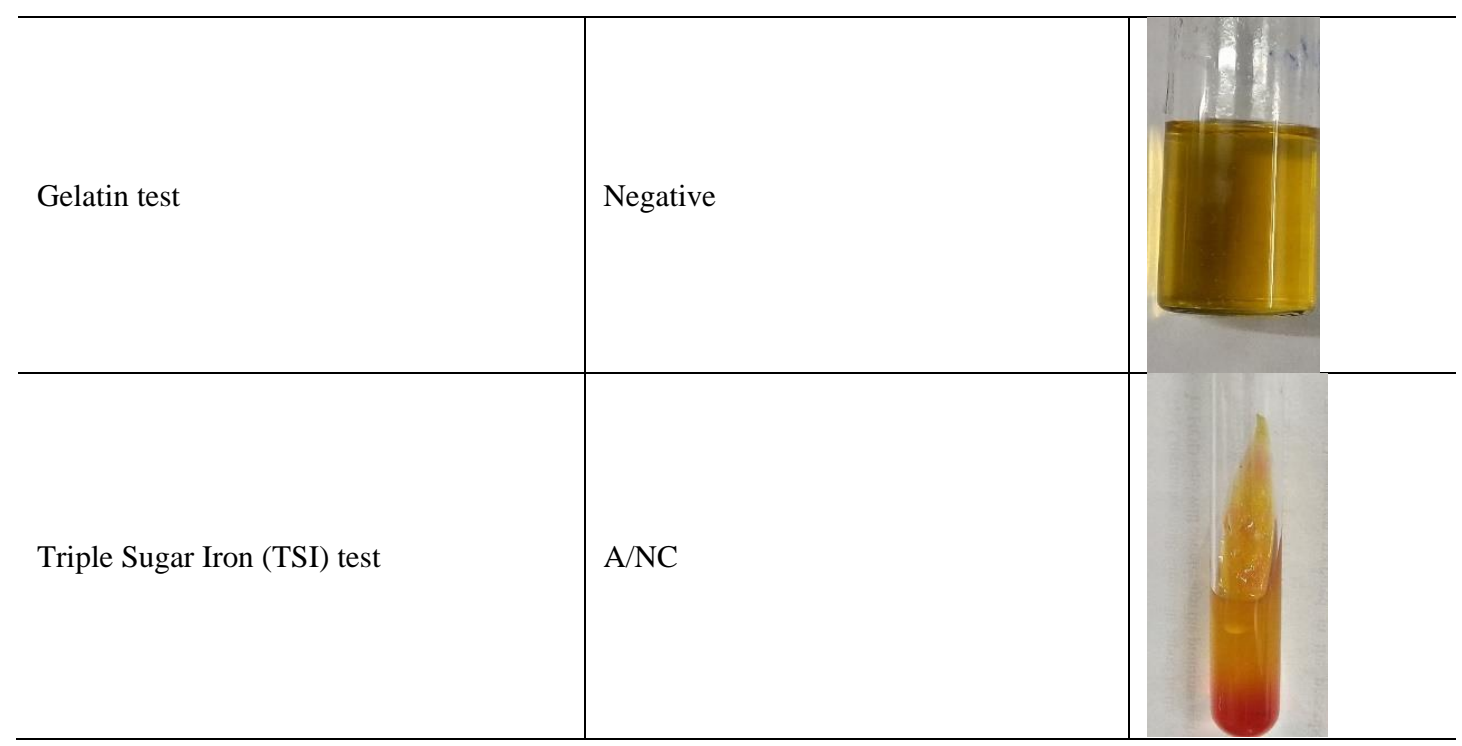

$\mathrm{A} / \mathrm{NC}$ stands for Acid/No Change $=$ Carbohydrate fermentation without growth in the anaerobic slant .

Based on the morphological and biochemical studies, the isolated strain was identified to be Hafnia sps.

\subsection{Total protein estimation.}

The BSA $(100 \mathrm{mg} / \mathrm{L})$ dilutions with absorbance at $750 \mathrm{~nm}$ were plotted in a graph, and the total protein of the isolate at $\mathrm{OD}_{750 \mathrm{~nm}}$ was found to be 1.850 after 24 hours of incubation and plotting from the BSA standard graph, the total protein in the isolate was found to be 410 $\mathrm{mg} / \mathrm{L}$.

\subsection{Cellulase degrading assay.}

The cellulolytic capacity of the isolate was tested on the Congo-Red agar medium, which showed gave a zone of clearance around the inoculum (Fig 2).

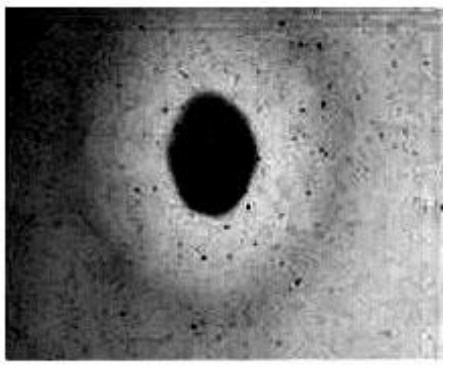

Figure 2. Congo-Red agar plate showing the zone of clearance.

The cellulolytic capacity of the isolate was put to comparison with that of a positive control Bacillus sps. The results are shown in Table 3, followed by the graph (Fig 3).

Table 3. The comparative study between the cellulolytic activity of $\mathrm{Cb} 1$ and Bacillus sps.

\begin{tabular}{l|l|l|l|l|l}
\hline Source & Isolate Number & $\begin{array}{l}\text { Maximum } \\
\text { clearing zone } \\
(\mathbf{m m})\end{array}$ & $\begin{array}{l}\text { Average HC } \\
\text { value }\end{array}$ & $\begin{array}{l}\text { Endoglucanse } \\
\text { activity range } \\
\text { (IU/mL) }\end{array}$ & $\begin{array}{l}\text { FPCase activity } \\
\text { range } \\
(\mathbf{I U} / \mathbf{m L})\end{array}$ \\
\hline C. chinense & $\mathrm{Cb} 1$ & 5.96 & 0.95 & 0.25 \\
\hline $\begin{array}{l}\text { Bacillus sps. } \\
\text { (Positive control) }\end{array}$ & $\mathrm{Cb} 0$ & 50 & 3.51 & 0.750 & 0.09 \\
\hline
\end{tabular}

Here, the HC value = ratio of Hydrolytic Capacity; FPCase activity=Filter Paper Cellulase activity. 


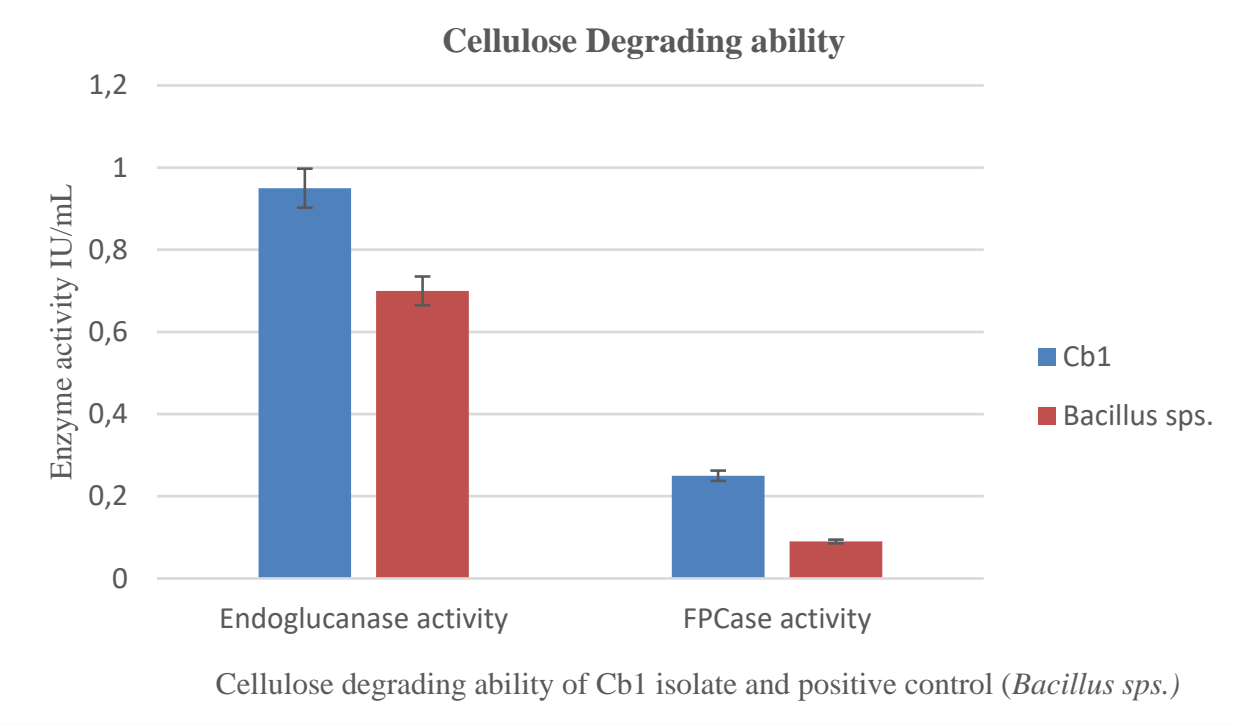

Figure 3. The comparative enzyme activity of endophyte $\mathrm{Cb} 1$ and Bacillus sps (Cb0).

\subsection{Statistical study.}

The one-way ANOVA results showed that the data was significant at $\mathrm{P}(<0.005)$ between the two groups, with the results run in triplicates.

\subsection{Discussion.}

The current study is the first approach to test the cellulolytic activity of bacterial endophytes isolated from $C$. chinense from North-East India. A recent study showed that bacterial species like Staphylococcus sps along with Escherichia coli, Enterobacter cancerogenus, S. Bacillus subtilis possess cellulolytic activity [32]. Another study showed such activity in Bacillus thuringeinsis, Brevibacillus brevis, Brevibacillus parabrevis, and Bacillus pumilus, B. licheniformis, B. methylotrophicus. Burkholderia sp. [33, 34, 35, 36, 37]. The endoglucanase from newly isolated cellulolytic bacteria $B$. safensis was successfully cloned and expressed in B. subtilis [38]. B. methylotrophicus extract that contains amylase is a potential candidate in environmental remediation processes for future use. [39].

Plant associated endophytes have always been a fascinating area of research for scientists. The North-eastern region of the country is known for its vast flora and its closely related endophytes. The microbial diversity of this region features a high level of endemism, and the region is considered a biodiversity hotspot. In this study, bacterial endophytes were isolated from the roots of $C$. chinense collected from the remote regions of North-east India. Out of all the isolates, one isolate showed the maximum cellulolytic activity. The cellulolytic capability of a microorganism is an area of immense potential in the field of environmental microbiology. The bacterial endophyte isolated from the roots of $C$. chinense was characterized both morphologically and biochemically and was placed under the genus Hafnia sp. The screening of this isolate for its cellulolytic potential by the use of the Congo-Red iodine test, followed by DNS test, showed its hydrolytic capability and cellulase enzyme production. Bacterial growth was confirmed by the absorbance at $600 \mathrm{~nm}$. The maximum clearing zone for the isolate was $50 \mathrm{~mm}$, and the hydrolytic capacity $(\mathrm{HC})$ was found to be 5.96. The endoglucanase activity ranged from $0.95 \mathrm{IU} / \mathrm{mL}$, and the filter paper Fpase activity was found to be $0.25 \mathrm{IU} / \mathrm{mL}$ 
The cellulolytic activity of the isolate was then compared with that of Bacillus sps. taken as a positive control. The results revealed that our isolate had a greater zone of clearance of $50 \mathrm{~mm}$ as compared to Bacillus, which was $40 \mathrm{~mm}$. Moreover, the isolate had greater endoglucanase and FPCase activity as compared to the Bacillus sps.

\section{Conclusions}

This is the first report on the cellulolytic activity of bacterial endophytes isolated from the roots of Capsicum chinense collected from North-East India. The current study shows the presence of endophytes in $C$. chinense roots collected from the North-east region of India. The study also shows the cellulolytic activitiy of the endophyte, which supports the presence of commercially important enzymes. In regard to the cellulolytic potential of the bacterial endophyte harboring in the root tissues of $C$. chinense, the conservation of such an economically important plant is very crucial. Further research is required to scale up the physiological and biochemical attributes of the bacterial endophytes from $C$. chinense such that cellulolytic potential can be further enhanced.

\section{Funding}

This research received fund from NE-DBT (Application No: AGRI/2015/48).

\section{Acknowledgments}

\section{Retd.Scientist from ICAR Prof. Amithabh Bandopadhyay for his guidance.}

\section{Conflicts of Interest}

The authors declare no conflict of interest.

\section{References}

1. Frey-Klett, P.; Burlinson, P.; Deveau, A.; Barret, M.; Tarkka, M.; Sarniguet, A. Bacterial-fungal interactions: hyphens between agricultural, clinical, environmental, and food microbiologists. Microbiol Mol Biol Rev 2011, 75, 583-609, https://doi.org/10.1128/mmbr.00020-11.

2. Hardoim, P.R.; van Overbeek, L.S.; Berg, G.; Pirttilä, A.M.; Compant, S.; Campisano, A.; Döring, M.; Sessitsch, A. The hidden world within plants: ecological and evolutionary considerations for defining functioning of microbial endophytes. Microbiol Mol Biol Rev 2015, 79, 293-320, https://doi.org/10.1128/mmbr.00050-14.

3. Tamosiune, I.; Baniulis, D.; Stanys, V. Role of Endophytic Bacteria in Stress Tolerance of Agricultural Plants: Diversity of Microorganisms and Molecular Mechanisms. In: Probiotics in Agroecosystem. Kumar, V.; Kumar, M.; Sharma, S.; Prasad, R. Eds. Springer Singapore: Singapore, 2017; pp. 1-29, https://doi.org/10.1007/978-981-10-4059-7_1.

4. Joshi, S.R.; Bhattacharjee, K.; Banerjee, A.; Bareh, D.A. Microbial diversity distribution in the lower belt of eastern Himalaya. Biodiversity in Tropical Ecosystems 2015, 261-288.

5. Samdhu, D.K.; Bawa, S. Improvement of cellulase activity in Trichoderma. Appl Biochem Biotech 1992, 34 35, 175-192, https://doi.org/10.1007/BF02920544.

6. Shewale, J.G. $\beta$-Glucosidase: Its role in cellulase synthesis and hydrolysis of cellulose. International Journal of Biochemistry 1982, 14, 435-443, https://doi.org/10.1016/0020-711X(82)90109-4.

7. Woodward, J.; Wiseman, A. Fungal and other $\beta$-d-glucosidases - Their properties and applications. Enzyme and Microbial Technology 1982, 4, 73-79, https://doi.org/10.1016/0141-0229(82)90084-9.

8. Ryu, D.D.Y.; Mandels, M. Cellulases: Biosynthesis and applications. Enzyme and Microbial Technology 1980, 2, 91-102, https://doi.org/10.1016/0141-0229(80)90063-0.

9. Wood, T.M.; McCrae, S.I.; Bhat, K.M. The mechanism of fungal cellulase action. Synergism between enzyme components of Penicillium pinophilum cellulase in solubilizing hydrogen bond-ordered cellulose. Biochemical Journal 1989, 260, 37-43, https://doi.org/10.1042/bj2600037. 
10. Lu, W.J.; Wang, H.T.; Nie, Y.F.; Wang, Z.C.; Huang, D.Y.; Qiu, X.Y.; Chen, J.C. Effect of inoculating flower stalks and vegetable waste with ligno-cellulolytic microorganisms on the composting process. $J$ Environ Sci Health B 2004, 39, 871-887.

11. Mswaka, A.Y.; Magan, N. Wood degradation, and cellulase and ligninase production, by Trametes and other wood-inhabiting basidiomycetes from indigenous forests of Zimbabwe. Mycological Research 1998, 102, 1399-1404, https://doi.org/10.1017/S0953756298006789.

12. Chakraborty, N.; Sarkar, G.M.; Lahiri, S.C. Cellulose degrading capabilities of cellulolytic bacteria isolated from the intestinal fluids of the silver cricket. Environmentalist 2000, 20, 9-11, https://doi.org/10.1023/A:1006691524607.

13. Ekperigin, M.M. Preliminary studies of cellulase production by Acinetobacter anitratus and Branhamella sp. Afr J Biotechnol 2007, 6, 28-33.

14. Vaithanomsat, P.; Chuichulcherm, S.; Apiwatanapiwat, W. Bioethanol production from enzymatically saccharified sunflower stalks using steam explosion as pretreatment. World Acad Sci Eng Technol 2009, 37, 140-143, https://doi.org/10.5281/zenodo.1054974.

15. Howard, L.R.; Wildman, R.E.C. Antioxidant vitamin and phytochemical content of fresh and processed pepper fruit (Capsicum annum). In: Handbook of nutraceuticals and functional foods. Ed. Wildman, REC. Boca Raton, FL: CRC Press, 2007; pp. 165-191.

16. Gogoi, B. Capsicum chinense Jacq. (Bhut Jolokia) - rich source of capsaicin with wide application and economic potential. Annals of Plant Sciences 2017, 6, 1664-1667, https://doi.org/10.21746/aps.2017.8.3.

17. Ratnaweera, P.B.; de Silva, E.D.; Williams, D.E.; Andersen, R.J. Antimicrobial activities of endophytic fungi obtained from the arid zone invasive plant Opuntia dillenii and the isolation of equisetin, from endophytic Fusarium sp. BMC Complem Altern M 2015, 15, https://doi.org/10.1186/s12906-015-0722-4.

18. Deeb, B.E.; Bazaid, S.; Gherbawy, Y.; Elhariry, H. Characterisation of endophytic bacteria associated with rose plant (Rosa damascene trigintipeta) during flowering stage and their plant growth promoting traits. J Plant Interact 2012, 7, 248-253, https://doi.org/10.1080/17429145.2011.637161.

19. Gerhardt, P.; Murray, R.G.E.; Wood, W.A.; Krieg, N.R. Methods for general and molecular Bacteriology. ASM Washington, 1994; pp, 518.

20. Lowry, O.H.; Rosenbrough, N.J.; Farr, A.L.; Randall, R.J. Protein measurement with the Folin Phenol Reagent. J Biol Chem 1951, 193, 265-275.

21. Maitra, S.S. Experimental determination of Kinetic parameters for anaerobic digestion of MsW leachate for prediction of contaminant transport through vadose zone. In: National convention on Biotechnology and the Environment held at NIT Durgapur. At NIT Durgapur 2010.

22. Hendricks, C.W.; Doyle, J.D.; Hugley, B. A new solid medium for enumerating cellulose-utilizing bacteria in soil. Applied and environmental microbiology 1995, 61, 2016-2019.

23. Liang, Y.L.; Zhang, Z.; Wu, M.; Wu, Y. Feng. J.X. Isolation, Screening, and identification of cellulolytic bacteria from Natural Reserves in the subtropical region of China and optimization of cellulose production by Paenibacillus terrare ME27-1. Biomed Res Int 2014, 2014, https://doi.org/10.1155/2014/512497.

24. Saha, S.; Roy, R.; Sen, S.K.; Ray, A.K. Characterisation of cellulase-producing bacteria from the digestive tract of Tilapia, Oreochromis mossambica (Peters) and grass carp, Ctenopharyngodon idella (Valenciennes). Aquac Res 2006, 37, 380-8, https://doi.org/10.1111/j.1365-2109.2006.01442.x.

25. Klemm, D.; Heublein, B.; Fink, H.-P.; Bohn, A. Cellulose: Fascinating Biopolymer and Sustainable Raw Material. Angewandte Chemie International Edition 2005, 44, 3358-3393, https://doi.org/10.1002/anie.200460587.

26. Shanmugapriya, K.; Saravana, P.S.; Krishnapriya, M.M.; Mythilli, A.; Joseph, S. Isolation, screening and partial purification of cellulose from cellulose producing bacteria. Int J Adv Biotechnol Res 2012, 3, 509-14.

27. Miller, G. L. Use of dinitrosalicylic acid reagent for determination of reducing sugar. Anal Chem 1959, 31, 426-428, https://doi.org/10.1021/ac60147a030.

28. Islam, F.; Roy, N. Screening, purification and characterization of cellulase from cellulase producing bacteria in molasses. BMC Research Notes 2018, 11, https://doi.org/10.1186/s13104-018-3558-4.

29. Bhat, M.K. Celluases and related enzymes in biotechnology. Adv Biotechnol 2000, 1, $355-83$. https://doi.org/10.1016/S0734-9750(00)00041-0.

30. Nandimath, A.P.; Kharat, K.R.; Gupta, S.G.; Kharat, A.S. Optimization of cellulase production for Bacillus sp. and Pseudomonas sp. soil isolates. Afr J Microbiol Res 2016, 10, 410-9, https://doi.org/10.5897/AJMR2016.7954.

31. Ghose, T.K. Mesurnment of cellulase activity. Pure Appl Chem 1987, 59, 257-268, https://doi.org/10.1351/pac198759020257.

32. Flimban, S.; Oh, S.-E.; Joo, J.H.; Hussein, K.A. Characterization and Identification of Cellulose-degrading Bacteria Isolated from a Microbial Fuel Cell Reactor. Biotechnology and Bioprocess Engineering 2019, 24, 622-631, https://doi.org/10.1007/s12257-019-0089-3.

33. Mohammed, R.; Salah, A.; Ahmed, B. Isolation and Identification of Cellulose Degrading Bacteria from Different Sources at Assiut Governorate (Upper Egypt). J Ecol Heal Environ Int J 2018, 6, 15-24, http://dx.doi.org/10.18576/jehe/060103. 
34. Chen, Z.; Meng, T.; Li, Z.; Liu, P.; Wang, Y.; He, N.; Liang, D. Characterization of a beta-glucosidase from Bacillus licheniformis and its effect on bioflocculant degradation. AMB Express 2017, 7, https://doi.org/10.1186/s13568-017-0501-3.

35. Ma, L.; Lu, Y.; Yan, H.; Wang, X.; Yi, Y.; Shan, Y.; Liu, B.; Zhou, Y.; Lü, X. Screening of cellulolytic bacteria from rotten wood of Qinling (China) for biomass degradation and cloning of cellulases from Bacillus methylotrophicus. BMC Biotechnology 2020, 20, https://doi.org/10.1186/s12896-019-0593-8.

36. Yang, C.X.; Wang, T.; Gao, L.N.; Yin, H.J.; Lü, X. Isolation, identification and characterization of lignindegrading bacteria from Qinling, China. J Appl Microbiol 2017, 123, 1447-1460, https://doi.org/10.1111/jam.13562.

37. Kazeem, M.O.; Shah, U.K.M.; Baharuddin, A.S.; AbdulRahman, N.A. Prospecting Agro-waste Cocktail: Supplementation for Cellulase Production by a Newly Isolated Thermophilic B. licheniformis 2D55. Appl Biochem Biotechnol 2017, 182, 1318-1340, https://doi.org/10.1007/s12010-017-2401-z.

38. Kanchanadumkerng, P.; Sakka, M.; Sakka, K.; Wiwat, C. Characterization and secretive expression in Bacillus subtilis of endoglucanase from Bacillus safensis isolated from freshwater swamp forest. Walailak $J$ Sci Technol (WJST) 2017, 14, 199-213.

39. Hmidet, N.; Jemil, N.; Nasri, M. Simultaneous production of alkaline amylase and biosurfactant by Bacillus methylotrophicus DCS1: application as detergent additive. Biodegradation 2019, 30, 247-258, https://doi.org/10.1007/s10532-018-9847-8.

40. Sharma, S.; Rashmitha, CS.; Pandey, LM. Synthesis and characterization of methyl acrylamide cellulose nanowhiskers for environmental applications Lett Appl NanoBioScience 2020, 9, 880 - 884. https://doi.org/10.33263/LIANBS91.880884.

41. Bayoumy, AM.; El-Sayed ESM.; Omar A.; Ibrahim M. Emerging applications of chitosan: from biology to environment. Biointerface Res Appl Chem 2018, 8, 3368 - 3380.

42. Tawfik, S.; Abd Elsalam, SH.; Nassar, SH.; Sehata, IA.; Elshemy, NS.; El-Thalouth, A. Microwave assisted chemical modification of starch in presence or absence of amylase enzyme and its application in textile printing. Lett Appl NanoBioScience 2019, 8, 762 - 769. https://doi.org/10.33263/LIANBS84.762769

43. Ezzat, HA.; Hegazy, MA.; Nada, NA.; Ibrahim, MA. Effect of nano metal oxides on the electronic properties of cellulose, chitosan and sodium alginate. Biointerface Res Appl Chem 2019, 9, 4143 - 4149. https://doi.org/10.33263/BRIAC94.143149. 